\title{
Farmers' perspectives on adoption and impacts of nutrition incentive and farm to school programs
}

\author{
Megan E. Lehnerd ${ }^{\text {a* }}$ \\ Tufts University \\ Jennifer M. Sacheck ${ }^{\mathrm{ab}}$ \\ Tufts University and The George Washington University \\ Timothy S. Griffin, , Jeanne P. Goldberg, and Sean B. Cash ${ }^{\text {a }}$ \\ Tufts University
}

Submitted November 30, 2017 / Revised January 18 and February 7, 2018 / Accepted February 7, 2018 /

Published online March 25, 2018 / Correction (Table 6 sample sizes) published June 15, 2018

Citation: Lehnerd, M. E., Sacheck, J. M., G riffin, T., S., G oldberg, J. P., \& Cash, S. B. (2018). Farmers' perspectives on adoption and impacts of nutrition incentive and farm to school programs. Journal of A griculture, F ood Systems, and C ommunity D evelopment, 8(1), 147-165.

https:/ / doi.org/ 10.5304/ jafscd.2018.081.012

Copyright @ 2018 by the Authors. Published by the Lyson Center for Civic Agriculture and Food Systems. Open access under CC BY license.

\begin{abstract}
Recent increases in consumer demand for local food have resulted in more opportunities for food to be purchased in close proximity to where it is produced. However, local markets can be challenging retail outlets for farmers and not uniformly affordable and accessible to all consumers. Farmers market nutrition incentive (FMNI) and farm to school (F2S) programs are two community-based initiatives that support farmers while simultane-
\end{abstract}

a * Corresponding author: Megan E. Lehnerd, Friedman School of Nutrition Science and Policy, Tufts University; 75 Kneeland Street, 8th Floor Suite; Boston, MA 02111 USA; mlehnerd@gmail.com

a Friedman School of Nutrition Science and Policy, Tufts University; 150 Harrison Avenue; Boston, MA 02111 USA. Co-author emails: Jennifer M. Sacheck: jsacheck25@ email.gwu.edu; Timothy S. G riffin: timothy.griffin@ tufts.edu; Jeanne P. G oldberg: jeanne.goldberg@ tufts.edu; Sean B. Cash: sean.cash@tufts.edu ously lessening the burden of local food access for lower income populations. In this study, we explore farmer perceptions, barriers to adoption, and impacts of FMNI and F2S programs. A survey was developed based on the Diffusion of Innovations theory to assess (1) the key factors that influence adoption of FMNI and F2S programs; (2) farmer perceptions of the most significant barriers to program adoption; and (3) the influence of noneconomic impacts on farmers' motivation to participate in those programs. A total of $155 \mathrm{Mid}-$ Atlantic fruit and vegetable farmers completed the

b Milken Institute School of Public Health, The G eorge Washington University; 950 New Hampshire Avenue; Washington, DC 20052 USA

\section{Funding Disclosure}

This material is based upon work that is supported by a grant from the Newman's O wn Foundation. The study sponsor had no role in the study design, analysis, writing, or decision to submit the report for publication. 
survey. Participating farmers perceived FMNI and F2S as providing advantageous social impact and various economic opportunities. However, participants and non-participants had differing perspectives on program complexity, compatibility with their business model, and the degree to which others have succeeded when participating. The most significant barriers relate to issues with product pricing, customer engagement, and logistics. Three-quarters of farmers ranked social/ community impacts as most important to them. A deeper understanding of farmers' involvement in FMNI and F2S programs will help address barriers and modify program components to increase economic, social/ community, and environmental impacts.

\section{Keywords}

Farmers Markets, Farm to School, Mid-Atlantic

Farmer, Fruit and Vegetable Farmer, Survey

D esign, Motivation, Barrier, Impact

\section{Introduction}

In recent years, farmers and consumers have become increasingly interested in selling and buying food within a local system. While the boundaries of "local" can vary, the Food, Conservation, and Energy Act of 2008 defined "local" or "regional" as an agricultural food product that was raised, produced, and distributed within 400 miles $(644 \mathrm{~km})$ of the product's origin or within the state where it was produced. According to the USD A National Agricultural Statistics Service's most recent Local Food Marketing Practices Survey, 167,009 farms nationwide took in US\$8.7 billion at local markets in 2015, with 35\% of these farms using direct-to-consumer (DTC) marketing channels, including farmers markets, community supported agriculture (CSAs), and roadside stands (USD A National Agricultural Statistics Service [USD A NASS], 2016). In addition, 39\% of these farms sell to institutions and intermediary channels such as schools, hospitals, food hubs, and wholesalers (USD A NASS, 2016).

Proponents of local food systems often associate them with benefits including more diversified farm income, environmental sustainability, farmland preservation, improved food quality, support for the local economy and community, and better health, nutrition, and food security (Abate, 2008; Martinez et al., 2010). Those with a more critical view warn that "local" as a geographic boundary cannot be inherently tied to any particular set of benefits (Born \& Purcell, 2006; Hinrichs, 2003). Over time, equity issues also have become apparent within the local food movement, as affordability and accessibility can be barriers to low-income consumers (Colasanti, Conner, \& Smalley, 2010; Leone et al., 2012; Lerman, 2012; Lowery, Sloane, Payán, Illum, \& Lewis, 2016). However, responses to these consumer inequities must also consider the need for farmers to have efficient access to profitable markets. The lack of clarity around the impact of local food systems and the tension between equity for farmers and consumers provide the primary motivation for this study: to explore farmer motivations for adoption, barriers to adoption, and the impacts surrounding two specific local food programs- farmers market nutrition incentive (FMNI) and farm to school (F2S) programs.

FMNI is an umbrella term referring to a collection of programs that offer financial incentives to increase the buying power of low-income consumers at farmers markets and other direct-toconsumer marketing channels. At the same time, they increase revenue for farmers selling at markets in lower-income neighborhoods or to lowerincome customers (Cole, McNees, Kinney, Fisher, \& K rieger, 2013; Community Science, 2013). FMNI programs originate at the federal level and are administered by state and local agencies. The incentive structure of the programs may include a free voucher, as in the WIC ${ }^{1}$ Farmers' Market Nutrition and Senior Farmers' Market Nutrition Programs (FMNP), or as a dollar-for-dollar match of the shoppers' own Supplemental Nutrition Assistance Program (SNAP) spending (Karakus, MacAllum, Milfort, \& Hao, 2014; Low et al., 2015).

F2S programs can also provide a market for locally grown agricultural products and have the potential to impact children's food knowledge and healthy development by linking agriculture, school

1 WIC is the federal Special Supplemental Nutrition Program for Women, Infants, and Children. 
gardens, and nutrition education et al., 2014). The 2015 USD A Farm to School Census reported that nationwide over $40 \%$ of surveyed schools participated in F2S activities, which may include buying and serving locally sourced food, tending to school gardens, and providing gardening and nutrition education. These schools represent a sizeable potential market to which local farmers could sell their produce (USD A Food and Nutrition Service, 2015). While the potential economic benefits for farmers from F2S come from local food sales, farmers may also engage with schools in other ways that can impact children and set the stage for future local food procurement, like visiting school gardens and cafeterias, hosting field trips, or providing food for taste tests (Joshi, Azuma, \& Feenstra, 2008).

There is limited generalizable evidence describing the benefits of and rationale for participating in FMNI and F2S programs from the perspective of producers. Some research has explored farmer participation in local food marketing channels and their motivations to engage in civic agriculture focused on local distribution and sustainable practices (Furman, Roncoli, Nelson, \& Hoogenboom, 2014; USD A NASS, 2016). One study noted the importance of nutrition incentives to sales at farmers markets (Cole et al., 2013), and another identified modest economic impacts for farmers selling in institutional markets (Sitaker, Kolodinsky, Seguin, \& Pitts, 2014). Research suggests that farmers seem to value impacts on health, education and community (Conner, Sevoian, Heiss, \& Berlin, 2011; Izumi, Wynne Wright, \& Hamm, 2010; Lazarus, 2014); however, it is unclear how strongly these factors motivate their decision to engage in FMNI and F2S programs. O ther studies have identified seasonality, consumer and school budget constraints, and imbalances between supply and demand as key barriers that prevent farmers from participating in these programs (Berkenkamp, 2012; Huff, 2015; Rosenberg, Truong, Russell, Abdul-Haqq, Gipson, \& Hickson, 2013). An additional study highlighted the creative supply chain and market strategies farmers employ to lessen these barriers (Feenstra, Allen, Hardesty, Ohmart, \& Perez, 2011). Overall, these studies are limited in scope and have focused primarily in the
Upper Midwest, the Northeast, and in California. More research is needed to understand the factors farmers consider when deciding whether to participate in FMNI and/ or F2S programs as well as the barriers that deter nonparticipants.

Research 0 bjective

The objective of this study was to understand the perspectives of fruit and vegetable farmers on the adoption and the impacts of FMNI and F2S programs. To do this, we developed and administered a survey to assess (1) the key factors that influence the adoption of FMNI and F2S programs; (2) their perceptions of the most significant barriers to program adoption; and (3) the influence of noneconomic factors on their motivation to adopt these programs. The Diffusion of Innovations (DI) theory was used to develop a framework for understanding FMNI and F2S program adoption (Rogers, 2003).

\section{Methods}

Farmer Survey D evelopment

The farmer survey was developed to explore the characteristics of FMNI and F2S programs that influence farmer participation as well as the perceived barriers and impacts of participation. The survey was composed of three main sections: (1) perceptions of FMNI and F2S as defined by four DI theory attributes (relative advantage, compatibility, complexity, and observability); (2) experienced or perceived barriers to program adoption; and (3) reported impacts of program adoption.

Perceptions of FM N I and F 2S framed by the $D$ iffusion of Innovations theory

First used in rural sociology in the 1940s and '50s, the DI theory has been adapted for use in many settings, including agriculture, to understand perceptions of new programs or technology and explain how innovations have spread (Hasin \& Smith, 2016; Rogers, 2003; Saltiel, Bauder, \& Palakovich, 1994). While multiple iterations of the DI theory exist, the four main theoretical constructs (innovation characteristics, communication channel, time, and social system) work to explain how and why diffusion occurs and the potential onsequenoes or 
outomes of that process (Rogers, 2003).

D I offered an appropriate framework for understanding the innovation characteristics of FMNI and F2S that influenced farmers' decisions to engage with these programs. The innovation characteristics outlined by the D I theory are defined as the perceived attributes that the potential adopter understands the innovation or intervention to offer. The five perceived attributes are relative advantage, compatibility, complexity, observability, and trialability. The attributes, their definitions, and the application of these characteristics are outlined in Table 1 (Rogers, 2003).

For each of the four DI theory attributes, variables were operationalized and survey questions developed based in part on a previously validated instrument (Hasin \& Smith 2016) which examined the diffusion of electronic benefits transfer (EBT) technology at farmers markets from the market manager's perspective. The questions were adapted using published research about farmer perspectives on FMNI and F2S programs (Atkinson, 2007; Pankratz, Hallfors, \& Cho, 2002). Theory variables were measured using a five-point Likert scale of agreement which was coded numerically for analysis ( $1=$ strongly disagree, $2=$ somewhat disagree, $3=$ neither agree nor disagree, $4=$ somewhat agree, 5=strongly agree).

Barriers to and Impacts of Program A doption Barriers to and impacts of program participation were synthesized from previously published literature regarding FMNI and F2S programs (Bateman, Engel, \& Meinen, 2014; Matts, Conner, Fisher, Tyler, \& Hamm, 2015; Washington State Department of Agriculture O ffice of Compliance and Outreach, 2012). Barriers were ranked on a four-point scale and then coded ( $1=$ not at all a barrier, $2=$ minor barrier, $3=$ major barrier, $4=$ not applicable). Farmers were asked to consider how FMNI and F2S participation impacted financial factors such as income and market access by indicating the degree to which they experienced a change (1=decreased greatly, $2=$ decreased some, $3=$ stayed the same, $4=$ increased some, $5=$ increased greatly, and $6=$ not applicable/ do not know). Impacts related to economic, social/ community, and environmental factors were included in separate sections of the survey, with the goal of having respondents rank the three most important factors within each category. When ranking their top three choices within each category, respondents could also indicate if a given category, for example economic impacts, was not important to them.

Table 1. Core Innovation Characteristics in the Diffusion of Innovations Theory

\begin{tabular}{lll}
\hline Attribute & Definition & Application \\
\hline Relative Advantage & $\begin{array}{l}\text { Perception that the innovation is } \\
\text { better than its predecessor. }\end{array}$ & $\begin{array}{l}\text { The benefits for farmers may be related to income, market } \\
\text { access, social status, or other factors. If a program is seen } \\
\text { as more beneficial when compared to other market options } \\
\text { (e.g., wholesale), the program is more likely to be adopted. }\end{array}$ \\
\hline Compatibility & $\begin{array}{l}\text { Perception that the innovation fits in } \\
\text { with the potential adopters' existing } \\
\text { values, experiences, and needs. }\end{array}$ & $\begin{array}{l}\text { When a program is consistent with a farmer's business } \\
\text { model, value system, or sociocultural view, he/ she is more } \\
\text { likely to participate. }\end{array}$ \\
\hline Complexitya & $\begin{array}{l}\text { Perceived level of difficulty to under- } \\
\text { stand and use the innovation or } \\
\text { adopt the intervention. }\end{array}$ & $\begin{array}{l}\text { Programs are less likely to be adopted when they are } \\
\text { perceived as complex to the farmer. }\end{array}$ \\
\hline Observability & $\begin{array}{l}\text { Degree to which results of the } \\
\text { innovation or program use are visible } \\
\text { to others. }\end{array}$ & $\begin{array}{l}\text { If a farmer is able to observe another farmer who has } \\
\text { chosen to participate in a program, they can observe how } \\
\text { the program works and the benefits of use. This makes the } \\
\text { farmer more likely to adopt, as well. }\end{array}$ \\
\hline Trialabilityb (omitted) & $\begin{array}{l}\text { Degree to which innovation can be } \\
\text { tried before adopting. }\end{array}$ & $\begin{array}{l}\text { If a program can be tried out before an adoption decision is } \\
\text { made, there is a greater likelihood of adoption. }\end{array}$ \\
\hline
\end{tabular}

a This attribute is the only one negatively related to adoption; therefore, some have used the term simplicity to maintain uniform directionality across all the attributes.

${ }^{b}$ In the case of programs like farmers market nutrition incentive (FMNI) and farm-to-schoo (F2S) programs, try-outs are not typically possible; therefore, this concept was not included in this study. 
Survey $\mathrm{V}$ alidity and Pilot T esting

Fourteen expert reviewers provided content validity feedback on the farmer survey with five reviewers providing feedback on the FMNI section, seven on the F2S section, and two on the application of DI theory. The experts represented a variety of backgrounds, including the nonprofit sector $(n=2)$, farming $(n=4)$, farming trade organizations $(\mathrm{n}=2)$, government $(\mathrm{n}=3)$, agriculture education and/ or training $(\mathrm{n}=1)$, and behavior change theory research $(n=2)$. The majority of feedback was related to question wording and missing concepts within the impact, barriers, and program characteristics categories. Content and design issues raised by expert reviewers were addressed prior to pilot testing.

In November and D ecember 2016, 13 farmers were asked to pilot-test the full survey. These farmers were recruited through one producer conference in New England, a state department of agriculture in New England, and regional agriculture working groups in New England and the Midwest region. Nine farmers participated in both FMNI and F2S, one in F2S only, two in FMNI only, and one in neither program. Each tester completed the survey on a Qualtrics web-based platform, either on a tablet provided to them by research staff or on their personal computer. Participants were asked to engage in a brief discussion following the completion of the survey to provide any additional feedback. Further edits were then made to the survey to clarify or remove questions that were duplicates, lacked relevance to the survey population, or were subject to substantial recall bias.

\section{Survey Sample}

The study was conducted using a cross-sectional sample of fruit and vegetable farmers in the MidAtlantic region during February and March 2017. The study targeted fruit and vegetable farmers because several FMNI programs are restricted to purchasing only fresh produce, and those types of local agricultural products also are most frequently purchased by schools (USD A Food and Nutrition Service, n.d., 2017). So far, there has been a lack of studies concerning FMNI and F2S programs in the Mid-A tlantic region- Pennsylvania, New Jersey, Delaware, Maryland, Virginia, West Virginia, and the $\mathrm{D}$ istrict of Columbia. To participate, farmers had to meet the following inclusion criteria. The farmer must have:

1. Produced and sold fruits or vegetables for human consumption in 2016;

2. Been an owner, co-owner, or primary decision-maker about marketing for the farm; and

3. Participated or considered participating in the FMNI and/ or F2S programs at their current operation.

Farmers were recruited using a snowball sampling technique, with initial contacts at two producer conferences in the Mid-Atlantic region. Additional participants were recruited through organizations and stakeholders in the Mid-Atlantic region with access to the population of interest (e.g., state extension offices, food hubs, nonprofit and/ or community organizations, regional agriculture working groups). Surveys were self-administered by respondents via $Q$ ualtrics, either by using a tablet provided by the on-site research team at conferences or by using their own personal computers. Respondents who indicated participation in FMNI and/ or F2S programs were prompted to answer all three sections of the survey. Those who had considered either program but chose not to participate (i.e., non-adopters) were only asked to complete survey sections one and two. The survey also inquired about demographic, socioeconomic, and farm business information. The study was approved by the researchers' university Institutional Review Board for human subjects research.

A nalysis

Means and standard deviations were calculated for each DI theory variable, and t-tests corrected for unequal variance were utilized to compare adopters and non-adopters in each program. Variables were grouped based on their connection to the four main DI theory attributes, and a summary score for each attribute was generated. Additional t-tests were conducted to compare FMNI and F2S adopters and non-adopters. Internal consistency using calculations of Cronbach's alpha were done to determine whether the variables composing each 
attribute were measuring the same concept, with alphas of $>0.65$ being considered acceptable (Goforth, 2015). For the DI attributes related to FMNI, all alphas were $>0.65$. For F2S, the alphas bordered 0.65 , with the attribute of complexity significantly below the cutoff at 0.47 . The lower F2S alphas were likely due to the small sample of F2S respondents. Therefore, the variables were all maintained in their respective categories, acknowledging the need for larger future samples to determine reliability.

The barriers for FMNI, sales to schools, and other F2S activities were calculated and ranked based on the percent of respondents indicating that an item was a major barrier. To determine what respondents perceived to be the most important impacts of FMNI and F2S programs, each suggested economic, social/ community, and environmental factor was reverse coded and totaled. Adopters were required to rank at least one but no more than three impacts within each category; therefore, the number of respondents for each item varied. Following the ranking, the top three factors in each category were selected based on their total score. The significance level was set at $p<0.05$ for all analyses. All analyses were conducted using Stata SE, version 14.2 (StataCorp LLC, 2017).

\section{Results}

\section{D escriptive Statistics}

Of those who met the inclusion criteria, a total of 195 surveys were attempted. However, responses were removed if a majority of questions were left unanswered (36 responses) or there were inconsistencies in the data that suggested a fraudulent submission (4 responses), resulting in a final sample size of 155 farmers. The sample size for each survey section is noted in the tables.

Concerning the programs of interest in this study, 104 farmers responded that they currently participate in FMNI, and 42 responded that they currently participate in F2S. Twenty-nine farmers indicated current adoption of both programs. Those who never considered adoption of FMNI $(\mathrm{n}=35)$ or F2S ( $\mathrm{n}=47)$ were separated from nonadopters (FMNI=38, F2S=66) and were not asked questions conceming their perceptions of program characteristics, barriers, and impacts as they would not likely have such perceptions. Farm and farmer characteristics are shown in Table 2. All six states in the Mid-Atlantic region and the D istrict of Columbia were represented in the sample. Based on the USDA definitions of farm size prior to the 2015 definition revisions, the majority of farmers oversaw farms that would be considered small, with $85.5 \%$ reporting annual sales below US $\$ 250,000$. Most respondents were female $(57.4 \%)$, White (87.1\%), and non-Hispanic $(91.6 \%)$. There were few differences in farmer demographics and farm characteristics between the adopters and non-adopters in either program; however, FMNI adopters had been farming for

Table 2. Farm and Farmer Characteristics $(n=155)$

\begin{tabular}{lc}
\hline Farm Location & $\%$ \\
\hline Pennsylvania & 36.1 \\
\hline Maryland & 25.8 \\
\hline Virginia & 18.1 \\
\hline West Virginia & 12.3 \\
\hline New Jersey & 3.9 \\
\hline Delaware & 1.9 \\
\hline Washington, DC & 1.9 \\
\hline
\end{tabular}

Farm Income, by Farm Size Category

\begin{tabular}{lc}
\hline Small farms (<US\$250K) & 85.8 \\
\hline Midsize farms (US\$250K- <US\$1 mil) & 8.4 \\
\hline Large farms (US\$1 mil- <US\$5 mil) & 4.5 \\
\hline Very large farms (>US\$5 mil) & 1.3 \\
\hline
\end{tabular}

Geographic Location

\begin{tabular}{ll}
\hline Rural & 74.2 \\
\hline Urban & 11.6 \\
\hline Suburban/semi-urban & 14.2 \\
\hline
\end{tabular}

Respondent Position

\begin{tabular}{lc}
\hline Owner or Co-owner & 76.1 \\
\hline General Non-owner Operator & 10.3 \\
\hline Production Manager & 5.2 \\
\hline Sales \& Marketing Manager & 6.5 \\
\hline Other, please share: & 1.9 \\
\hline & mean (SD) \\
\hline Age & $42.9(13.4)$ \\
\hline Years farming & $13.5(11.6)$ \\
\hline
\end{tabular}


Journal of Agriculture, Food Systems, and Community Development

ISSN: 2152-0801 online

https:/ / www.foodsystemsjournal.org

almost five years longer than non-adopters (14.8 years versus 10.0 years, $p=0.02$ ).

D ata were also gathered about the types and duration of FMNI and F2S engagement reported by farmers to provide a sense of how program participation has changed over time (Appendix, Table A1). The largest number of farmers reported that their farm was authorized to accept WIC or Senior Farmers'Mmarket vouchers, with 25\% doing so for more than 10 years. Farmers engaging in F2S most frequently reported providing produce to schools for samples or tastings $(n=31)$, with most having engaged in that practice for 1 to 3 years $(51.6 \%)$.
Farmers Mark et N utrition Program Results

D ifferences in program perception

Table 3 displays the differences between the perceptions of adopters and non-adopters regarding FMNI, all of which were significantly different except for the attribute of observability. The most substantial difference was related to the attribute of complexity, which has been reverse coded in order to provide uniform directionality across all DI factor categories. We interpret this as adopters perceiving the ease of participation to be a mean of 3.4 (out of 5) which differs significantly from nonadopters, who perceive the ease of participation to

Table 3. Diffusion of Innovation Theory Factors Influencing Farmers Market Nutrition Incentive (FM NI) Program Adoption

\begin{tabular}{|c|c|c|c|c|}
\hline \multirow[b]{2}{*}{ DI Theory Factor } & \multirow{2}{*}{$\begin{array}{c}\text { Magnitude of } \\
\text { difference in means } \\
\text { (absolute value) }\end{array}$} & $\begin{array}{c}\text { Adopters } \\
(\mathrm{n}=104)\end{array}$ & $\begin{array}{c}\text { Non-adopters } \\
(n=38)\end{array}$ & \multirow[b]{2}{*}{ p-value* } \\
\hline & & \multicolumn{2}{|c|}{ Mean value on scale $(\mathrm{sd})^{\mathrm{a}}$} & \\
\hline Complexityb & 1.0 & $3.4(0.84)$ & $2.4(0.71)$ & 0.0000 \\
\hline Compatibility & 0.5 & $4.5(0.62)$ & $4.0(0.69)$ & 0.0004 \\
\hline Relative Advantage & 0.4 & $4.3(0.68)$ & $3.9(0.73)$ & 0.0015 \\
\hline Observability & 0.1 & $3.6(0.43)$ & $3.5(0.56)$ & 0.5434 \\
\hline
\end{tabular}

a Data are presented as the overall mean score (standard deviation) on 1- 5 scale where 1 is strongly disagree $\& 5$ is strongly agree.

b Note that the scale for the complexity category has been reversed to maintain a uniform directionality across all categories, meaning a high score equates to less complexity.

$*$ p-values in bold show statistical significance at $<0.05$

Table 4. Top Five Reported Barriers and Perceived Barriers of Farmers Market Nutrition Incentive (FM NI) Program Adoption a

\begin{tabular}{|c|c|c|c|}
\hline & Major barrier & Minor barrier & Not at all \\
\hline \multicolumn{4}{|l|}{ Adopters ( $n=104)$} \\
\hline Customers can't afford the prices I have to charge & 24.0 & 51.0 & 20.2 \\
\hline Volume needs of FMNI markets are too small & 15.5 & 27.2 & 42.7 \\
\hline $\begin{array}{l}\text { Marketing of the FMNI program by market manager or FM NI program } \\
\text { leader is not adequate }\end{array}$ & 15.4 & 33.7 & 41.4 \\
\hline Customer interest in the produce I sell & 14.4 & 49.0 & 34.6 \\
\hline Logistics of transporting product to FMNI market locations & 6.7 & 14.4 & 69.2 \\
\hline \multicolumn{4}{|l|}{ Non-adopters $(n=38)$} \\
\hline Paperwork required to participate in FMNI programs & 47.4 & 44.7 & 2.6 \\
\hline Availability of training about FMNI program & 44.7 & 44.7 & 5.3 \\
\hline Receiving prompt payment & 31.6 & 31.6 & 26.3 \\
\hline Establishing/maintaining farmers' market or FMNI program relationships & 29.0 & 42.1 & 15.8 \\
\hline $\begin{array}{l}\text { The marketing of the FMNI program by market manager or FMNI program } \\
\text { leader is not adequate }\end{array}$ & 29.0 & 23.7 & 29.0 \\
\hline
\end{tabular}

a Data are presented as \% of respondents identifying each factor as a barrier. Responses are ranked based on the top five most reported major barriers for adopters and non-adopters within each category. Rows may not add up to $100 \%$ because the "not applicable" category is not shown here. 
be a mean of 2.4. Tables A2 and A3 (Appendix) present the detailed comparison of the individual variables composing the four D I theory attributes. As expected, FMNI program adopters showed significantly more favorable perceptions of program characteristics than FMNI non-adopters.

Barriers to participation

Table 4 presents differences in the top five reported barriers to participation in FMNI stratified by adopters and non-adopters. Both FMNI adopters and non-adopters saw the marketing of the program to be a concern. Just over $15 \%$ of adopters and $29 \%$ of non-adopters perceived marketing to be a major barrier. Otherwise, perceptions of top barriers differed between the two groups. Adopters largely cited customer and market characteristics as key barriers, while non-adopters were concerned more with program logistics. O verall, non-adopters saw more barriers to program engagement than adopters.

Impacts of participation

Sixty-four percent of FMNI adopters reported that, overall, farm income increased some or greatly as a result of participation. They also reported that the types of markets accessed were either the same or slightly more varied and diverse than before program adoption. As a part of their overall farm sales, FMNI adopters also observed increases in the percent of sales from farmers markets and farm stands (55\%). When asked which category of impacts were most important to them, $74 \%$ of FMNI farmers ranked social/ community impacts highest, with economic and environmental impacts being of lesser importance. Table 5 further illustrates the top three most important impacts within each category. For $44.2 \%$ of FMNI famers, helping to feed low-income individuals was the most important social/ community impact. Twentyone percent of FMNI farmers indicated that economic factors were not a motivation for them. O verall, environmental factors were of lower importance to adopters in both programs.

\section{Farm to School Program Results}

$D$ ifferences in program perception O nly perceptions of relative advantage and observability significantly differed between F2S adopters and non-adopters (Table 6). For example, adopters perceived $\mathrm{F} 2 \mathrm{~S}$ to be advantageous with a mean score of 4 (out of 5), while the mean score for non-adopters was 3.5. Program perceptions tended to be similar between adopters and nonadopters among individual questions, especially

Table 5. Impacts of Farmers Market Nutrition Incentive (FM NI) Program Participation ( $\mathrm{n}=104)^{\mathrm{a}}$

\begin{tabular}{|c|c|c|c|c|}
\hline \multirow[b]{2}{*}{ Category of Impact } & \multirow{2}{*}{$\begin{array}{l}\% \text { ranking as top } \\
\text { impact category }\end{array}$} & \multicolumn{3}{|c|}{ within category, \% ranking as... } \\
\hline & & 1st & 2nd & $3 \mathrm{rd}$ \\
\hline Social/ community Impacts & 74.0 & & & \\
\hline Helps to feed low-income individuals & & 44.2 & 22.1 & 9.6 \\
\hline Positively impacts the nutrition $\&$ health of the community & & 19.2 & 47.1 & 14.4 \\
\hline Raises public awareness about food \& farming & & 9.6 & 11.5 & 27.9 \\
\hline Economic Impacts & 23.1 & & & \\
\hline Increases my sales at existing markets & & 47.1 & 14.4 & 6.7 \\
\hline $\begin{array}{l}\text { Allows me to charge a fair price, since low income shoppers have } \\
\text { help buying my produce }\end{array}$ & & 17.3 & 28.9 & 13.5 \\
\hline Not motivated by economic factors & & 21.2 & 2.9 & 9.6 \\
\hline Environmental Impacts & 1.9 & & & \\
\hline Have customers that value more sustainable growing practices & & 38.5 & 17.3 & 3.9 \\
\hline Not motivated by environmental factors & & 33.7 & 1.9 & 1.9 \\
\hline Help me to keep my land in farming instead of another use & & 17.3 & 11.5 & 9.6 \\
\hline
\end{tabular}

a Represented here are the top three most important factors by category. They are listed largest to smallest in terms of the total number of respondents ranking each factor in their top three choices of impacts. 
Journal of Agriculture, Food Systems, and Community Development ISSN: 2152-0801 online

https:/ / www.foodsystemsjournal.org

Table 6. Diffusion of Innovation Theory Factors Influencing Farm-to-School (F2S) Program Adoption

\begin{tabular}{lcccc}
\hline & Magnitude of difference & Adopters & Non-adopters \\
in means & $(\mathrm{n}=66)$ & \\
\cline { 3 - 3 } DI Theory Factor & (absolute value) & Mean value on scale (sd) & p-value* \\
\hline Relative Advantage & 0.5 & $4.0(0.14)$ & $3.5(0.11)$ & 0.0118 \\
Observability & 0.4 & $3.2(0.11)$ & $2.8(0.09)$ & 0.0068 \\
Complexity* & 0.3 & $2.9(0.11)$ & $2.6(0.11)$ & 0.1059 \\
Compatibility & 0.1 & $3.9(0.07)$ & $3.8(0.07)$ & 0.1333 \\
\hline
\end{tabular}

a Data are presented as the overall mean score (standard deviation) on 1-5 scale where 1 is strongly disagree and 5 is strongly agree.

b Note that the scale for the complexity category has been reversed to maintain a uniform directionality across all categories, meaning a high score equates to less complexity.

$*$ p-values in bold show statistical significance at $<0.05$

Table 7. Top Five Reported Barriers/ Perceived Barriers of Farm-to-School (F2S) Program Adoptiona

\begin{tabular}{|c|c|c|c|}
\hline Potential Barriers to F2S Sales & Major barrier & Minor barrier & Not at all \\
\hline \multicolumn{4}{|l|}{ Adopters $(n=42)$} \\
\hline $\begin{array}{l}\text { Schools lack the capacity to do scratch cooking or serve fresh food (e.g., } \\
\text { staff skills, equipment, space) }\end{array}$ & 52.4 & 16.7 & 11.9 \\
\hline School(s) offer low purchase price and/or have food budget constraints & 40.5 & 31.0 & 14.3 \\
\hline $\begin{array}{l}\text { Lack of investment from the food service director or manager to engage } \\
\text { in farm to school sales and activities }\end{array}$ & 35.7 & 28.6 & 16.7 \\
\hline Contract/ bidding process that is required by school district(s) & 33.3 & 26.2 & 9.5 \\
\hline Volume needs of schools are too large & 28.6 & 21.4 & 31.0 \\
\hline \multicolumn{4}{|l|}{ Non-adopters $(n=66)$} \\
\hline $\begin{array}{l}\text { Schools lack the capacity to do scratch cooking or serve fresh food (e.g., } \\
\text { staff skills, equipment, space) }\end{array}$ & 52.3 & 20.0 & 9.2 \\
\hline Volume needs of schools are too large & 50.8 & 21.5 & 15.4 \\
\hline Contract/ bidding process that is required by school district(s) & 50.8 & 18.5 & 7.7 \\
\hline $\begin{array}{l}\text { Lack of knowledge about which schools are interested in buying directly } \\
\text { from farms }\end{array}$ & 50.8 & 26.2 & 10.8 \\
\hline Seasonality of my products don't match with school year & 49.2 & 24.6 & 10.8 \\
\hline Potential Barriers to Other F2S Activities & Major barrier & Minor barrier & Not at all \\
\hline \multicolumn{4}{|l|}{ Adopters $(n=42)$} \\
\hline Logistical challenges in coordinating visits to classrooms or cafeterias & 19.1 & 40.5 & 16.7 \\
\hline The time involved in visiting classrooms or cafeterias & 19.1 & 28.6 & 28.6 \\
\hline The time involved in hosting field trips at my farm & 11.9 & 31.0 & 31.0 \\
\hline The cost of bring students to my farm for field trips & 11.9 & 23.8 & 33.3 \\
\hline Logistical challenges in coordinating field trips to my farm & 9.5 & 31.0 & 35.7 \\
\hline \multicolumn{4}{|l|}{ Non-adopters $(n=66)$} \\
\hline The cost of bring students to my farm for field trips & 21.5 & 20.0 & 33.9 \\
\hline Logistical challenges in coordinating visits to classrooms or cafeterias & 18.5 & 33.9 & 26.2 \\
\hline Logistical challenges in coordinating field trips to my farm & 15.6 & 28.1 & 32.8 \\
\hline The time involved in hosting field trips at my farm & 15.6 & 28.1 & 34.4 \\
\hline The time involved in visiting classrooms or cafeterias & 9.2 & 35.4 & 32.3 \\
\hline
\end{tabular}

a Data are presented as \% of respondents identifying each factor as a barrier. Responses are ranked based on the top five most reported major barriers for adopters and non-adopters within each category. Rows may not add up to $100 \%$ because the "not applicable" category is not shown here. 
those related to the attributes of complexity and compatibility; however the reliability of the complexity measure (as indicated by Cronbach's alpha) was marginal (Appendix Tables A2 and A3).

\section{Barriers to participation}

Both F2S adopters and non-adopters ranked the limited capacity of schools to cook from scratch as the most substantial barrier to engagement in F2S sales (Table 7), with approximately $52 \%$ of respondents in each group ranking it as a major barrier. Issues with contract and/ or bidding processes and the large volume needs of schools were also in the top five for both groups. The remaining barriers differed between the two, with adopters experiencing challenges with school budget constraints and a lack of investment by food service leadership. Major challenges related to other F2S activities were reported less frequently than with F2S sales. For both sets of F2S barriers, non-adopters generally ranked items as major barriers more often than adopters.

\section{Impacts of participation}

Fifty percent of F2S adopters reported overall farm income increasing some or greatly as a result of participation. The variety of markets accessed was perceived to be the same or slightly higher than before program adoption. F2S adopters largely reported no changes to the variety of products they sell. Seventy-nine percent of adopters ranked social/ community impacts of highest importance, followed by economic and environmental impacts (Table 8). Specifically, teaching kids about farming and food production was cited as the most important social/ community impact. Thirty-one percent of F2S adopters were not motivated by economic factors, and environmental factors were also of lower importance overall.

\section{Discussion}

With the goal of more deeply understanding the adoption, barriers, and impacts of FMNI and F2S programs, our survey of Mid-A tlantic fruit and vegetable farmers uniquely captured the perspectives of both program adopters and non-adopters. O ur results indicate that adopters of both FMNI and F2S perceive the programs to be more advantageous than non-adopters, specifically related to the potential social impact and market opportunities provided by these programs. However, adopters and non-adopters differed in their perceptions of program characteristics and perceived barriers to adoption in ways that likely impact the decision to participate in FMNI and F2S programs. The most frequently reported barriers concerned issues with product pricing, customer engagement, program logistics, and administration.

Table 8. Impacts of Farm-to-School (F2S) Program Participation ( $n=42)^{\text {a }}$

\begin{tabular}{|c|c|c|c|c|}
\hline \multirow[b]{2}{*}{ Category of Impact } & \multirow{2}{*}{$\begin{array}{l}\text { \% ranking as top } \\
\text { impact category }\end{array}$} & \multicolumn{3}{|c|}{ within category, \% ranking as... } \\
\hline & & 1st & $2 n d$ & $3 r d$ \\
\hline Social/ community Impacts & 78.6 & & & \\
\hline Teach kids about farming and how food grows & & 33.3 & 23.8 & 21.4 \\
\hline Positively impact the nutrition $\&$ health of kids & & 21.4 & 23.8 & 21.4 \\
\hline Help build relationships between me and nearby communities & & 23.8 & 11.9 & 19.1 \\
\hline Economic Impacts & 21.4 & & & \\
\hline Not motivated by economic factors. & & 31.0 & 2.4 & 0.0 \\
\hline Help to build my future customer base & & 11.9 & 16.7 & 7.1 \\
\hline Provide me with large volume orders & & 14.3 & 11.9 & 4.8 \\
\hline Environmental Impacts & 0.0 & & & \\
\hline Teach kids about environmental issues and sustainable farming & & 69.1 & 4.8 & 2.4 \\
\hline Keeps "seconds" or lower grade produce from being wasted & & 7.1 & 16.7 & 4.8 \\
\hline Support lower transportation emissions by keeping my distribution local & & 2.4 & 16.7 & 9.5 \\
\hline
\end{tabular}

a Represented here are the top three most important factors by category. They are listed largest to smallest in terms of the total number of respondents ranking each factor in their top three choices of impacts. 
Social/ community impacts were a clear motivating factor for farmers, with approximately $75 \%$ of respondents ranking those impacts as most important in deciding whether or not to participate.

\section{FM N I Program Perceptions and Barriers}

The DI theory framework helped to illuminate certain differences in program perceptions that may lead to program adoption. We found that FMNI adopters perceived the program to be less complex, more advantageous, and more compatible with their business model and values than non-adopters. Even with these differences, we still found that non-adopters appreciate the role of FMNI in community food systems to the same degree as adopters and find value in supporting food access for low-income communities. The more substantial differences were related to perceptions of the program structure and logistics, encompassed by the attributes of relative advantage and compatibility. The differences between FMNI adopters and non-adopters indicate that once farmers participate in the program, they no longer view issues like payment, program procedures, and the fit of the program into their business model as concerns. Outreach to potential participants by FMNI sponsoring agencies and farmers markets could more explicitly highlight that logistical aspects of the program are not as burdensome as they may seem. Furthermore, outreach could also highlight that support is available at the state and local level to navigate program administration.

These differences in program perception also relate to the perceived barriers to FMNI participation. There was a general consensus that market managers could improve the advertising of the FMNI programs. Successful pilot projects and a recent USD A Food and Nutrition Service study (Karakus et al., 2014; Low et al., 2015) found that low-income survey respondents were 40 times more likely to shop at farmers markets if they had knowledge of these markets providing incentives for SNAP participants. With this in mind, improved marketing of the program could help mitigate affordability issues and increase farmer revenue. 0 ther barriers experienced by FMNI adopters were related to customer budgets, the preference for certain food items, the volume needs of the market, and the logistics of transport to market locations. To address cost issues, some farmers and markets have established "pay-whatyou-can" or sliding scale models. O thers have chosen to host a CSA pick-up site at lower income markets to help to create more efficient food distribution. While more difficult to coordinate, assessing the community's food preferences in order to shift growing practices, offering cooking demonstrations, and providing taste tests may be additional ways to increase the sale of produce items.

For non-adopters, perceived barriers relate mostly to issues of start-up and program logistics. Knowing that these issues are not relevant for adopters, it is essential that recruitment efforts clearly explain the logistical ease of the program and that trainings provided by state and local level program administrators are accessible to potential adopters. FMNI program sponsoring agencies could further improve their reach through the development of recruitment partnerships with new farmer training programs, state extension offices, and other groups focused on market access for small to midsize producers.

\section{F2S Program Perceptions and Barriers}

Similar to FMNI respondents, all F2S respondents viewed school-based local agriculture programs as valuable within community food systems and prioritize providing food to local school children. Not surprisingly, F2S adopters perceive the program to be more advantageous and a better fit with their business model than non-adopters, which may explain in part their decision to participate. However, it is notable that program complexity and logistics are a concern regardless of participation status. While this may not be surprising, more research with a larger sample of farmers participating in F2S programs may be needed to understand why some farmers choose to engage despite knowing about these challenges while others do not. While difficult to execute, there is still room to improve the technical and logistical support available to farmers interested in engaging with schools. These improvements include assistance with building relationships with potential school partners, navigating the contracting and bidding process, and 
managing produce deliveries. The provision and marketing of this additional support could help shift the mindset of those who have chosen not to participate.

Regarding F2S sales, both adopters and nonadopters saw the lack of capacity of schools to scratch cook or serve freshly prepared food (compared to serving frozen, heat-and-serve meals) as the biggest barrier. This is not a new concern, as many school districts have shifted away from scratch cooking since the early 1980s. At that time, large-scale budget cuts forced schools to reduce spending on food and labor while also increasing business. This often meant serving quick, "kidfriendly" meals like pizza and fries that required less skill, thus saving money and staff time (Poppendieck, 2011). Partially in response to the lack of scratch cooking capacity and other F2S barriers, federal-level support for F2S was formally established in the 2010 Healthy Hunger Free Kids Act. This legislation created a USD A F2S program to fund training and technical assistance for key program stakeholders through a competitive grant program. Additional initiatives at the federal, state, and local levels have even been put into place to help districts procure kitchen equipment to process and store fresh food, which might include items like large-capacity food processors, knife sets, cutting boards, and additional refrigeration space (The Pew Charitable Trusts, 2013; USDA Food and Nutrition Service, 2014). Efforts have also been made to provide culinary training and professional development for food service staff (Cohen, Richardson, Cluggish, Parker, Catalano, \& Rimm, 2015; Dill, 2017; Stephens \& Byker Shanks, 2015). D espite these advancements, there is still a need to invest in school and kitchen infrastructure upgrades and more widespread food service staff training to support a shift towards more scratch cooking in school meal programs.

O ther barriers cited by both F2S adopters and non-adopters included the burdensome contract and bidding process and the fact that school volume needs may exceed farmers' capacity. To help better understand procurement issues, a pilot project within the 2014 farm bill created more flexibility for eight states to use geographic preference to purchase unprocessed, local fruits and vegetables using USD A dollars slated to school meal purchases (Low et al., 2015). G eographic preference is a strategy used by school districts during contracting and bidding processes that allows local producers to receive "preference points" when their proposal is being weighed against other, non-local producers (USD A Farm to School Program, 2014). States and localities have also passed legislation making it easier for school districts to give preference to local food producers when making purchases (Low et al., 2015). Additionally, it is becoming more common for school districts and external partners to engage in collective bidding processes and coordinate bulk food purchases in order to lessen these as challenges (Conner, Nowak, Berkenkamp, Feenstra, Van Soelen Kim, Liquori, \& Hamm, 2011). Matching programs and technology platforms have been successful at better synchronizing school supply with farmer demand, which may be a barrier that aggregators can help address. G eographic preference policies and other types of logistical support await further evaluation regarding their effectiveness in increasing farmer participation in F2S programs. If successful, these strategies could offer support to allow these programs to expand.

Lastly, it is noteworthy that fewer logistical and financial barriers are present when considering other F2S activities beyond sales, such as engaging in classroom and cafeteria visits and hosting field trips. These activities may not have a significant financial impact for farmers in the short term, but may influence children's future food purchasing decisions. For farmers interested in engaging with schools for the first time, these activities present low hanging fruit that may assist them in developing relationships with food service staff and gaining a greater understanding for school food demands, while potentially leading to more in-depth involvement in F2S activities and sales.

Impacts of F M I and F2S Participation When considering the impact of FMNI and F2S programs within the local food movement, often the selling point for participation is diversified market opportunities for farmers and increased revenue. However, we found that farmers report being most driven by the urge to support their 
community. Not only are farmers socially motivated, but social/ community impacts were ranked as overwhelmingly more important than either economic or environmental impacts for both FMNI and F2S respondents. In fact, a substantial portion of respondents indicated that economic impacts were not ranked in their top three. Of course, it is still important to highlight the economic impacts of these programs in conjunction with the social impacts, as it is essential that engagement in FMNI and F2S is profitable for farmers. Respondents indicated that both programs helped to increase overall farm income, which is key to the long-term retention of farmers within these programs. Lastly, environmental factors were of tangential importance to farmers when thinking about the overall impacts of FMNI and F2S. In addition, there may be differences in how farmers rank environmental impacts based on their choice of farming practices (i.e. organic, certified naturally grown). More research is needed to explore that potential distinction.

\section{Strengths and L imitations}

A major strength of this study was the use of the DI theory as a framework for understanding the adoption of FMNI and F2S programs. The D I theory suggests that, as information about an innovation is communicated over time among members of a social system, adoption of the innovation will occur in waves. Innovations that require new technology, are complex, or are composed of a cluster of components tend to take longer to adopt (Rogers, 2003). Understanding these elements within the context of FMNI and F2S programs helps to illuminate how the adoption of each program has occurred. While this study provides a very preliminary glimpse at the timeline by which FMNI and F2S program adoption has occurred, more research is needed to understand how those who adopted in the first wave differ from those at later phases of adoption. In the future, measuring the communication channel and social system supporting program adoption will further enhance these research findings. Unfortunately, the crosssectional and largely retrospective nature of this study limited our ability to collect those data. Another strength of this study was the inclusion of both program adopters and non-adopters, allowing us to uniquely capture the perspectives of those who have considered participation but chose not to engage. The insights of non-adopters are key when strategizing about recruitment and retention of future program participants. Limitations did include the small sample size and the possible sampling error (e.g., selection bias) resulting from the snowball sample. D ue to the sampling strategy and geographic constraints on the study population, the results may not be representative of produce farmers throughout the Mid-Atlantic or the broader United States, and generalizability is limited. Lastly, there may be instances where recall bias was a factor, especially for farmers who were asked to recall the factors that influenced decisions they made years ago.

\section{Implications}

Knowing that FMNI and F2S programs strive to alleviate local food system inequities and provide more diversified markets for farmers, the findings from this study can improve program design and implementation and aid in recruiting additional FMNI and F2S adopters. FMNI and F2S sponsoring organizations may find success developing recruitment and technical assistance partnerships with more traditional agricultural agencies, like the Farm Bureau, state extension, and offices of rural development, agricultural marketing, as well as family and small farms. With their broader stakeholder base and existing infrastructure, these types of agencies would help to reach farmers that may not have considered FMNI or F2S and could provide a stronger foundation for program delivery.

This study also provides evidence about the importance of programs like FMNI and F2S for America's farmers. Legislative and funding support is essential to ensure that these programs continue successfully in the 2018 farm bill. Efforts should focus on maintaining the Food Insecurity Nutrition Incentive Grant Program, the Farmers Market and Local Food Promotion Program, Specialty Crop Block Grants, Community Food Projects, and the Senior Farmers Market Nutrition Program. Additionally, strengthening state and local contracting and bidding policies to minimize local food 
procurement barriers and supporting an increase in school meal reimbursement amounts would enhance the ability of schools to buy from local farms. Building on the results of this and prior studies, future research related to FMNI and F2S programs is needed to capture longitudinal impacts on the local economy, child and community health outcomes, and community food security.

\section{Acknowledgments}

Thank you to our research assistant, Rebecca Lucas, who played an instrumental role in this study, and to all the partners who helped to recruit pilot testers and survey participants: the Northeast Sustainable Agriculture Working G roup, the Pennsylvania Alliance for Sustainable Agriculture, and the West Virginia Small
Farms Conference. Additionally, we would like to recognize the content experts who provided guidance on survey development: Sara Folta, Tufts Friedman School of Nutrition; Beatrice Rogers, Tufts Friedman School; Anupama Joshi, National Farm to School Network; Jim Barham, USD A Rural D evelopment; Matt Benson, USD A Food and Nutrition Service; Jennifer O badia, Healthcare Without Harm; Karen Fedor, Maryland D epartment of Agriculture; D anielle Fluery, USD A Community Food Systems Northeast Region; Roger Noonan, New England Farmers Union; Brian Bates, Bear Creek Organic Farm; D aniel Key, Truffula Farm; Meredith Epstein, University of Maryland Institute of Applied Agriculture; Ellen Schramm, Mountain View Farm; and D avid Marvel, D avid Marvel Farms.

\section{References}

Abate, G . (2008). Local food economies: D riving forces, challenges, and future prospects. Journal of $\mathrm{H}$ unger \& E nvironmental N utrition, 3(4), 384-399. https:/ / doi.org/ 10.1080/ 19320240802528914

Atkinson, N. L. (2007). D eveloping a questionnaire to measure perceived attributes of eHealth innovations. A merican Journal of $H$ ealth Behavior, 31(6), 612-621. https:/ / doi.org/ 10.5993/ AJHB.31.6.6

Bateman, J., Engel, T., \& Meinen, A. (2014). Understanding Wisconsin producer and distributor perceptions to inform farm to school programs and policies. Journal of $H$ unger \& E nvironmental $N$ utrition, 9(1), 48-63. https:/ / doi.org/ 10.1080/ 19320248.2013.840548

Berkenkamp, J. (2012). G rower perspectives on farm to school: A survey of interested farmers, ranchers and other producers. Minneapolis, Minnesota: Institute for Agriculture and Trade Policy. Retrieved from https:// www.iatp.org/ documents/ grower-perspectives-on-farm-to-school

Bom, B., \& Purcell, M. (2006). Avoiding the local trap: Scale and food systems in planning research. Journal of Planning E ducation and Research, 26(2), 195-207. https:// doi.org/ 10.1177/ 0739456x06291389

Cohen, J. F. W., Richardson, S. A., Cluggish, S. A., Parker, E., Catalano, P. J., \& Rimm, E. B. (2015). Effects of choice architecture and chef-enhanced meals on the selection and consumption of healthier school foods: A randomized clinical trial. JA MA Pediatrics, 169(5), 431-437. https:/ / doi.org/ 10.1001/ jamapediatrics.2014.3805

Colasanti, K. J. A., Conner, D. S., \& Smalley, S. B. (2010). Understanding barriers to farmers' market patronage in Michigan: Perspectives from marginalized populations. Journal of $\mathrm{H}$ unger \& E nvironmental $\mathrm{N}$ utrition, 5(3), 316-338. https:// doi.org/ 10.1080/ 19320248.2010.504097

Cole, K., McNees, M., Kinney, K., Fisher, K., \& Krieger, J. W. (2013). Increasing access to farmers markets for beneficiaries of nutrition assistance: Evaluation of the farmers market access project. Preventing $\mathrm{C}$ hronic $\mathrm{D}$ isease, 10, 114. https:/ / doi.org/ 10.5888/ pcd10.130121

Community Science. (2013). SN A P healthy food inœentives duster evaluation - 2013 final report. G aithersburg, Maryland: Author. Retrieved from https:/ / fairfoodnetwork.org/ resources/ healthy-food-incentives-cluster-evaluation-2013final-report/

Conner, D. S., Nowak, A., Berkenkamp, J., Feenstra, G. W., Van Soelen Kim, J., Liquori, T., \& Hamm, M. W. (2011). Value chains for sustainable procurement in large school districts: Fostering partnerships. Journal of A griaulture, F ood Systems, and Community D evelopment, 1(4), 55-68. https:/ / doi.org/ 10.5304/ jafscd.2011.014.005

Conner, D. S., Sevoian, N., Heiss, S. N., \& Berlin, L. (2014). The diverse values and motivations of Vermont farm to institution supply chain actors. Journal of A gricultural and E nvironmental E thics, 27(5), 695- 713. https:/ / doi.org/ 10.1007/ s10806-013-9485-4 
Journal of Agriculture, Food Systems, and Community D evelopment

ISSN: 2152-0801 online

https:/ / www.foodsystemsjournal.org

Dill, A. (2017). Increasing scratch cooking in Wisconsin schools through culinary training. Journal of $\mathrm{N}$ utrition $\mathrm{E}$ ducation and Behavior, 49(7), S125-S126. https:// doi.org/ 10.1016/j.jneb.2017.05.074

Feenstra, G., Allen, P., Hardesty, S., O hmart, J., \& Perez, J. (2011). Using a supply chain analysis to assess the sustainability of farm-to-institution programs. Journal of A griculture, F ood Systems, and C ommunity D evelopment, 1(4), 6985. https:// doi.org/ 10.5304/jafscd.2011.014.009

Food, Conservation, and Energy Act of 2008, 7 U.S.C. § 6015. (2008). Retrieved from http:/ / www.agriculture.senate.gov/ imo/ media/ doc/ pl110-246.pdf

Furman, C., Roncoli, C., Nelson, D . R., \& Hoogenboom, G. (2014). G rowing food, growing a movement: climate adaptation and civic agriculture in the southeastern United States. A griculture and $\mathrm{H}$ uman V alues, 31(1), 69-82. https:/ / doi.org/ 10.1007/ s10460-013-9458-2

Goforth, C. (2015, November 16). Using and Interpreting Cronbach's Alpha. Retrieved from the University of Virginia Library Research D ata Services + Sciences website: http:/ / data.library.virginia.edu/ using-and-interpretingcronbachs-alpha/

Hasin, A., \& Smith, S. (2016). The diffusion of Electronic Benefit Transfer (EBT) technology at Illinois farmers' markets: Measuring the perceived attributes of the innovation. Journal of $\mathrm{H}$ unger \& E nvironmental $\mathrm{N}$ utrition, 11(3), 354-369. https:// doi.org/ 10.1080/ 19320248.2015.1128861

Hinrichs, C. C. (2003). The practice and politics of food system localization. Journal of Rural Studies, 19(1), 33-45. https:// doi.org/ 10.1016/ S0743-0167(02)00040-2

Huff, P. (2015). Building M innesota's farm to institution mark ets: A producer survey. Minneapolis, Minnesota: Institute for Agriculture and Trade Policy. Retrieved from https:/ / www.iatp.org/ video/ building-minnesotas-farm-to-institutionmarkets-the-producer-perspective

Izumi, B. T., Wynne Wright, D ., \& Hamm, M. W. (2010). Market diversification and social benefits: Motivations of farmers participating in farm to school programs. Journal of Rural Studies, 26(4), 374-382. https:// doi.org/ 10.1016/ j.jrurstud.2010.02.002

Joshi, A., Azuma, A. M., \& Feenstra, G . (2008). D o farm-to-school programs make a difference? Findings and future research needs. Journal of $\mathrm{H}$ unger \& E nvironmental $\mathrm{N}$ utrition, 3(2-3), 229-246. https:/ / doi.org/ 10.1080/ 19320240802244025

Karakus, M., MacAllum, K., Milfort, R., \& Hao, H. (2014). N utrition assistance in farmers mark ets: U nderstanding the shopping patterns of SN A P participants. Prepared by Westat for the U.S. D epartment of Agriculture, Food and Nutrition Service. Retrieved from https:/ / www.fns.usda.gov/ snap/ nutrition-assistance-farmers-markets-understandingshopping-patterns-snap-participants

Lazarus, J. A . (2014). U nderstanding grower and producer motivations for participation in F arm to School programs (Master's thesis). North Dakota State University, Fargo. https:/ / hdl.handle.net/ 10365/ 27548

Leone, L. A., Beth, D ., Ickes, S. B., Macguire, K., Nelson, E., Smith, R. A.,... Ammerman, A. S. (2012). Attitudes toward fruit and vegetable consumption and farmers' market usage among low-income North Carolinians. Journal of $\mathrm{H}$ unger \& E nvironmental N utrition, 7(1), 64- 76. https:/ / doi.org/ 10.1080/ 19320248.2012.651386

Lerman, T. (2012). A review of scholarly literature on values-based supply chains. Agricultural Sustainability Institute, University of California, D avis. Retrieved from http:/ / asi.ucdavis.edu/programs/ sarep/ research-initiatives/ fs/ supply/ foodhubs-and-values-based-supply-chains

Lowery, B., Sloane, D ., Payán, D., Illum, J., \& Lewis, L. (2016). D o farmers' markets increase access to healthy foods for all communities? Comparing markets in 24 neighborhoods in Los Angeles. Journal of the A merican Planning A ssociation, 82(3), 252---266. https:/ / doi.org/ 10.1080/ 01944363.2016.1181000

Low, S. A., Adalja, A., Beaulieu, E., Key, N., Martinez, S., Melton, A.,... Vogel, S. (2015). Trends in U.S. local and regional food systems: A report to C ongress (No. 068). U.S. D epartment of Agriculture, Economic Research Service. Retrieved from https:// www.ers.usda.gov/ publications/ pub-details/?pubid=42807

Martinez, S., Hand, M., D a Pra, M., Pollack, S., Ralston, K., Smith, T.,... Newman, C. (2010). L ocal food systems: C onœpts, impacts, and issues (No. 97). U.S. D epartment of Agriculture, Economic Research Service. Retrieved from https:/ / www.ers.usda.gov/ publications/ pub-details/?pubid=46395 
Matts, C., Conner, D. S., Fisher, C., Tyler, S., \& Hamm, M. W. (2015). Farmer perspectives of farm to institution in Michigan: 2012 survey results of vegetable farmers. Renewable A griaulture and Food Systems, 31(1), 60- 71. https:/ / doi.org/ 10.1017/ S1742170514000465

Pankratz, M., Hallfors, D., \& Cho, H. (2002). Measuring perceptions of innovation adoption: The diffusion of a federal drug prevention policy. H ealth E ducation Research, 17(3), 315-326. https:/ / doi.org/ 10.1093/ her/ 17.3.315

Pew Charitable Trusts, The. (2013, D ecember 18). Kids' Safe and H ealth F oods Project: W hat does a school kitchen need? Retrieved from http:// pew.org/ 1YkUF4B

Poppendieck, J. (2011). F ree for all: Fix ing school food in A merica. Berkeley: University of California Press.

Rogers, E. M. (2003). D iffusion of innovations (5th ed.). New Y ork: Free Press.

Rosenberg, N., Truong, N. L., Russell, T., Abdul-Haqq, D ., Gipson, J. A., \& Hickson, D . A. (2013). Farmers' perceptions of local food procurement, Mississippi, 2013. Preventing C hronic D isease, 11. https:// doi.org/ 10.5888/pcd11.140004

Saltiel, J., Bauder, J. W., \& Palakovich, S. (1994). Adoption of sustainable agricultural practices: D iffusion, farm structure, and profitability. Rural Sociology, 59(2), 333-349. https:/ / doi.org/ 10.1111/ j.1549-0831.1994.tb00536.x

Sitaker, M., Kolodinsky, J., Seguin, R. A., \& Pitts, S. (2014). D o entrepreneurial food systems innovations impact rural economies and health? Evidence and gaps. A merican Journal of E ntrepreneurship, 7(2), 3-16. Retrieved from http:// www.ncbi.nlm.nih.gov/ pmc/ articles/ PMC4657568/

StataCorp LLC. (2017). Stata SE version 1.42. College Station, Texas: StataCorp LLC.

Stephens, L., \& Byker Shanks, C. (2015). K-12 school food service staff training interventions: A review of the literature. Journal of School H ealth, 85(12), 825-832. https:// doi.org/ 10.1111/ josh.12338

U.S. D epartment of Agriculture [USD A] Farm to School Program. (2014). G eographic preferenoe: W hat it is and how to use it [Fact Sheet]. Retrieved from https:/ / www.fns.usda.gov/ farmtoschool/ farm-school-resources

USD A Food and Nutrition Service [USD A FNS]. (n.d.). F arm to school census, 2015. Retrieved June 27, 2016, from https:// farmtoschoolcensus.fns.usda.gov/

USD A FNS. (2014, April 18). USDA awards grants for new school food service equipment to help schools dish up healthy meals [Press release no. 0065.14]. Retrieved from https:// www.fns.usda.gov/ pressrelease/ 2014/ 006514

USD A FNS. (2017, June 8). W IC farmers' mark et nutrition program (F M N P). Retrieved January 8, 2018, from https:// www.fns.usda.gov/ fmnp/ wic-farmers-market-nutrition-program-fmnp

USD A National Agricultural Statistics Service. (2016). H ighlights: D irect farm sales of food: Results from the 2015 local food mark eting practios survey. Retrieved from https:/ / www.agcensus.usda.gov/ Publications/Local Food/

Washington State Department of Agriculture Office of Compliance and O utreach. (2012). W SD A survey for farmers and producers - $\mathrm{G}$ eneral servios and farm to school [O nline survey instrument]. Retrieved from http:/ / www.farmtoschool.org/ Resources/ WSD A\%20Farm-to-School\%20Producer\%20Survey\%202012.pdf

Yoder, A. B., Liebhart, J. L., McCarty, D . J., Meinen, A., Schoeller, D ., Vargas, C., \& LaRowe, T. (2014). Farm to elementary school programming increases access to fruits and vegetables and increases their consumption among those with low intake. Journal of N utrition E ducation and Behavior, 46(5), 341-349.

https:// doi.org/ 10.1016/j.jneb.2014.04.297 


\section{Appendix}

Table A1. Length of Participation by Program

\begin{tabular}{|c|c|c|c|c|c|}
\hline Farm Nutrition Incentive Program Activities & $\mathrm{N}$ & 1 to $<3$ yrs & 3 to $<5$ yrs & 5 to $<10$ yrs & $>10 \mathrm{yrs}$ \\
\hline $\begin{array}{l}\text { My farm is authorized to accept WIC or Senior Farmers' } \\
\text { Market vouchers (FMNP). }\end{array}$ & 83 & $22.89 \%$ & $31.33 \%$ & $20.48 \%$ & $25.30 \%$ \\
\hline $\begin{array}{l}\text { Through the farmers' market management, my farm } \\
\text { accepts WIC or Senior Farmers' Market vouchers } \\
\text { (FMNP). }\end{array}$ & 62 & 24.19 & 24.19 & 25.81 & 25.81 \\
\hline $\begin{array}{l}\text { Through the farmers' market management where I sell, } \\
\text { SNAP/EBT shoppers spending is matched. }\end{array}$ & 52 & 36.54 & 30.77 & 28.85 & 3.85 \\
\hline $\begin{array}{l}\text { My farm accepts vouchers or matches SNAP spending for } \\
\text { Community Supported Agriculture (CSA) bundles. }\end{array}$ & 21 & 38.10 & 52.38 & 9.52 & 0.00 \\
\hline $\begin{array}{l}\text { My farm sells box/ bundle of produce delivered directly to } \\
\text { low income or senior shoppers (i.e., as a part of the } \\
\text { Commodity Supplemental Food Program). }\end{array}$ & 15 & 46.67 & 33.33 & 13.33 & 6.67 \\
\hline Farm to School Activities & $\mathrm{N}$ & 1 to $<3$ yrs & 3 to $<5$ yrs & 5 to $<10$ yrs & $>10 \mathrm{yrs}$ \\
\hline Provided produce to a school for samples or tastings & 31 & $51.61 \%$ & $22.58 \%$ & $12.90 \%$ & $12.9 \%$ \\
\hline Hosted a school group at your farm & 29 & 37.93 & 13.79 & 31.03 & 17.24 \\
\hline $\begin{array}{l}\text { Was a guest speaker in a classroom or at educational } \\
\text { event at a school }\end{array}$ & 28 & 39.29 & 25.00 & 25.00 & 10.71 \\
\hline $\begin{array}{l}\text { Worked with a school food service director or farm to } \\
\text { school program lead to plan for future sales }\end{array}$ & 23 & 69.57 & 13.04 & 13.04 & 4.35 \\
\hline $\begin{array}{l}\text { Sold one or more types of vegetables directly to one or } \\
\text { more schools }\end{array}$ & 22 & 54.55 & 27.27 & 18.18 & 0.00 \\
\hline $\begin{array}{l}\text { Provided a school with marketing or promotional materials } \\
\text { about your farm }\end{array}$ & 21 & 57.14 & 4.76 & 28.57 & 9.52 \\
\hline $\begin{array}{l}\text { Sold one or more types of fruit directly to one or more } \\
\text { schools }\end{array}$ & 18 & 44.44 & 39.89 & 5.56 & 11.11 \\
\hline Attended a school meal as a guest & 15 & 66.67 & 13.33 & 13.33 & 6.67 \\
\hline $\begin{array}{l}\text { Attended a National Farm to School Month event at a } \\
\text { school or in community }\end{array}$ & 14 & 64.29 & 14.29 & 14.29 & 7.14 \\
\hline $\begin{array}{l}\text { Sold other products (e.g. meat, eggs, dairy) directly to one } \\
\text { or more schools }\end{array}$ & 5 & 80.00 & 0.00 & 20.00 & 0.00 \\
\hline Other & 5 & 40.00 & 20.00 & 40.00 & 0.00 \\
\hline
\end{tabular}

Note: Data are presented as the $\%$ of farmers engaging in each activity for the designated number of years. 
Table A2. Components of Diffusion of Innovation Theory Score, Factors Influencing Farmers Market Nutrition Incentive (FM NI) Adopters and Non-Adopters

\begin{tabular}{|c|c|c|c|c|}
\hline \multirow[b]{2}{*}{ DI Theory Factor } & \multirow{2}{*}{$\begin{array}{c}\text { Magnitude of } \\
\text { difference in } \\
\text { means } \\
\text { (in absolute value) }\end{array}$} & $\begin{array}{c}\text { Adopters } \\
(n=104)\end{array}$ & $\begin{array}{c}\text { Non-adopters } \\
(\mathrm{n}=38)\end{array}$ & \multirow[b]{2}{*}{$p$-value } \\
\hline & & \multicolumn{2}{|c|}{ Mean value on scale (sd)a } & \\
\hline \multicolumn{5}{|l|}{ Compatibility } \\
\hline $\begin{array}{l}\text { Accepting FMNI would fit in with my system for } \\
\text { collecting payment }\end{array}$ & 1.3 & $4.2(1.04)$ & $2.9(1.23)$ & 0.0000 \\
\hline $\begin{array}{l}\text { Selling at markets with an FMNI program could fit } \\
\text { easily into a farm's business plan }\end{array}$ & 0.6 & $4.4(0.82)$ & $3.9(1.21)$ & 0.0094 \\
\hline $\begin{array}{l}\text { I value helping lower income shoppers get local fruits } \\
\text { and vegetables }\end{array}$ & 0.0 & $4.8(0.60)$ & $4.8(0.62)$ & 0.7369 \\
\hline $\begin{array}{l}\text { FMNI programs are an important part of the local } \\
\text { food movement }\end{array}$ & 0.1 & $4.5(0.74)$ & $4.4(0.95)$ & 0.4925 \\
\hline \multicolumn{5}{|l|}{ Relative Advantage } \\
\hline $\begin{array}{l}\text { Benefits of participating in FMNI programs outweigh } \\
\text { the challenges }\end{array}$ & 0.9 & $4.4(0.85)$ & $3.5(1.11)$ & 0.0000 \\
\hline $\begin{array}{l}\text { FMNI would increase the sales of farmers who } \\
\text { participate }\end{array}$ & 0.6 & $4.4(0.82)$ & $3.8(0.96)$ & 0.0025 \\
\hline $\begin{array}{l}\text { FMNI programs would bring more customers to the } \\
\text { farmers' market }\end{array}$ & 0.4 & $4.3(0.83)$ & $3.9(1.02)$ & 0.0464 \\
\hline $\begin{array}{l}\text { FMNI would help farmers reach neighborhoods or } \\
\text { markets that they might not have before }\end{array}$ & 0.1 & $4.3(0.85)$ & $4.4(0.64)$ & 0.6117 \\
\hline \multicolumn{5}{|l|}{ Complexity } \\
\hline $\begin{array}{l}\text { Getting reimbursed as a part of the FMNI program } \\
\text { could require too many steps }{ }^{b}\end{array}$ & 1.3 & $2.4(1.12)$ & $3.7(0.90)$ & 0.0000 \\
\hline $\begin{array}{l}\text { Information about FMNI programs is easy to } \\
\text { understand }\end{array}$ & 1.1 & $3.9(1.02)$ & $2.8(1.15)$ & 0.0000 \\
\hline $\begin{array}{l}\text { Process of participating in FMNI (paperwork, } \\
\text { accounting, labor, etc.) would take more time and } \\
\text { effortb }\end{array}$ & 0.7 & $3.4(1.16)$ & $4.0(0.82)$ & 0.0004 \\
\hline \multicolumn{5}{|l|}{ Observability } \\
\hline $\begin{array}{l}\text { Other farmers had experienced problems when } \\
\text { participating in FMNI programs }\end{array}$ & 0.6 & $2.8(0.95)$ & $3.4(0.75)$ & 0.0003 \\
\hline Customers seemed satisfied with the FMNI program & 0.5 & $4.2(0.76)$ & $3.7(0.96)$ & 0.0048 \\
\hline $\begin{array}{l}\text { Other farmers and vendors seem satisfied with the } \\
\text { FMNI program }\end{array}$ & 0.3 & $3.7(0.84)$ & $3.5(0.95)$ & 0.1468 \\
\hline
\end{tabular}

a Data are presented as the overall mean score (standard deviation) on 1-5 scale where 1 is strongly disagree and 5 is strongly agree. ${ }^{b}$ Reverse coded for the overall average DI theory component score in Table 3.

p-values in bold show statistical significance at $<0.05$ 
Journal of Agriculture, Food Systems, and Community D evelopment ISSN : 2152-0801 online

https:/ / www.foodsystemsjournal.org

Table A3. Components of Diffusion of Innovation Theory Score, Factors Influencing Farm to School (F2S) Program Adopters and Non-Adopters

\begin{tabular}{|c|c|c|c|c|}
\hline \multirow[b]{2}{*}{ DI Theory Factor } & \multirow{2}{*}{$\begin{array}{l}\text { Magnitude of } \\
\text { difference in } \\
\text { means } \\
\text { (absolute value) }\end{array}$} & $\begin{array}{c}\text { Adopters } \\
(n=42)\end{array}$ & $\begin{array}{c}\text { Non-adopters } \\
(n=66)\end{array}$ & \multirow[b]{2}{*}{ p-value } \\
\hline & & \multicolumn{2}{|c|}{ Mean value on scale $(\mathrm{sd})^{\mathrm{a}}$} & \\
\hline \multicolumn{5}{|l|}{ Relative Advantage } \\
\hline $\begin{array}{l}\text { Benefits of participating in F2S programs would } \\
\text { outweigh the challenges }\end{array}$ & 0.8 & $3.9(1.09)$ & $3.1(1.22)$ & 0.0004 \\
\hline $\begin{array}{l}\text { F2S programs diversify farmers' economic } \\
\text { opportunities }\end{array}$ & 0.1 & $4.0(0.95)$ & $4.0(0.90)$ & 0.7073 \\
\hline \multicolumn{5}{|l|}{ Compatibility } \\
\hline $\begin{array}{l}\text { Selling to a school or schools can fit easily into the } \\
\text { business plan for a farm }\end{array}$ & 0.6 & $3.7(1.16)$ & $3.1(1.31)$ & 0.0137 \\
\hline $\begin{array}{l}\text { F2S programs are an important part of the local food } \\
\text { movement }\end{array}$ & 0.4 & $4.6(0.59)$ & $4.2(1.06)$ & 0.0187 \\
\hline $\begin{array}{l}\text { Selling to a school or schools would require more } \\
\text { effort than selling to other types of markets }\end{array}$ & 0.3 & $4.1(0.99)$ & $3.7(1.29)$ & 0.1297 \\
\hline $\begin{array}{l}\text { I highly value helping children access local foods } \\
\text { (such as local fruits and vegetables) }\end{array}$ & 0.1 & $4.7(0.68)$ & $4.6(0.80)$ & 0.4916 \\
\hline $\begin{array}{l}\text { I highly value teaching kids about farms and the job } \\
\text { of farmers }\end{array}$ & 0.0 & $4.7(0.74)$ & $4.7(0.70)$ & 0.9042 \\
\hline \multicolumn{5}{|l|}{ Complexity } \\
\hline $\begin{array}{l}\text { Information would be easily available explaining how } \\
\text { to contact schools about working together }\end{array}$ & 0.3 & $3.2(1.13)$ & $2.9(1.38)$ & 0.164 \\
\hline $\begin{array}{l}\text { There would be adequate step-by-step instructions } \\
\text { on how to participate in a F2S program }\end{array}$ & 0.3 & $3.4(1.13)$ & $3.1(1.27)$ & 0.171 \\
\hline $\begin{array}{l}\text { Process of participating in F2S (paperwork, } \\
\text { accounting, labor, etc.) would take more time and } \\
\text { effortb }\end{array}$ & 0.1 & $4.0(1.01)$ & $4.1(0.92)$ & 0.6392 \\
\hline \multicolumn{5}{|l|}{ Observability } \\
\hline Schools seemed satisfied with the F2S program & 0.6 & $3.6(1.01)$ & $3.1(0.85)$ & 0.0021 \\
\hline $\begin{array}{l}\text { Other farmers seemed satisfied when selling to } \\
\text { schools or doing F2S activities }\end{array}$ & 0.4 & $3.3(1.00)$ & $2.9(0.97)$ & 0.0433 \\
\hline $\begin{array}{l}\text { Other farmers had experienced problems when } \\
\text { working with schoolsb }\end{array}$ & 0.2 & $3.3(0.68)$ & $3.5(0.81)$ & 0.2284 \\
\hline
\end{tabular}

a Data are presented as the overall mean score (standard deviation) on 1- 5 scale where 1 is strongly disagree and 5 is strongly agree.

b Reverse coded for the overall average DI theory component score in Table 6.

p-values in bold show statistical significance at $<0.05$ 